\title{
Plan spawania wymiennika ciepła 65 kW
}

\section{A plan of welding the $65 \mathrm{~kW}$ plate heat exchanger}

\section{Streszczenie}

Przedstawiono plan spawania wymiennika ciepła 65 kW. Przedstawiono stosowane materiały podstawowe i dodatkowe do spawania, technologię spawania oraz wymagania dla personelu spawalniczego. Omówiono zagadnienia dotyczące przygotowanie elementów do spawania, prostowania po spawaniu, badań nieniszczących oraz naprawy wadliwych złączy. Zaprezentowano zagadnienia dotyczące spawania komór przejściowych, wstępnego spawania komory spalania oraz montażu i spawania konstrukcji wymiennika.

Słowa kluczowe: spawanie; plan spawania; wymiennik ciepła; technologia spawania

\begin{abstract}
A plan of welding the $65 \mathrm{~kW}$ plate heat exchanger is presented in the article. Basic and filler materials used in welding, technology of welding, as well as the requirements relating to the welding personnel are shown. Issues referring to the preparation of elements to welding, straightening after welding, non-destructive testing, and reparation of faulty joints are described. Problems of welding transient chambers, initial welding of combustion chambers, and an assembly and welding the frame of the plate heat exchanger are provided.
\end{abstract}

Keywords: welding; plan of welding; plate heat exchanger; technology of welding

\begin{abstract}
Wstęp
Konstrukcje spawane wykonuje się wykorzystując posiadane urządzenia i umiejętności w zakresie stosowanej metody spawania. W celu zapewnienia spawanym wyrobom wymagane kształty, jakość połączeń spawanych i wysoką wydajność ich wytwarzania, sporządza się Technologiczne plany spawania. Zawierają one przebieg czynności które należy wykonać w celu wytworzenia wyrobu. Technologiczny plan spawania tworzy się na podstawie dokumentacji technicznej wyrobu, zweryfikowaną pod kątem wymagań spawalniczych przez personel nadzoru nad pracami spawalniczymi zakładu wykonującego ten wyrób [16 $\div 33]$.
\end{abstract}

\section{Instrukcja spawania}

\section{Zakres stosowania}

Niniejsza instrukcja dotyczy wykonania wymiennika ciepła metodą 141. Obejmuje ona spawanie elementów ze stali wysokostopowej X5CrNI18-10.

\section{Materiały podstawowe}

Materiałem podstawowym dla wykonania wymiennika wina być stal konstrukcyjna wysokostopowa X5CrNi18-10 stosowana w przemyśle spożywczym, chemicznym, transporcie. Dobrze spawalna nie wymaga podgrzewania przed i po spawaniu. Odstępstwem jest wyżarzanie odprężające w przypadku stosowania w środowisku gdzie może wystąpić korozja naprężeniowa.

\section{Materiały dodatkowe}

Do wykonania wymiennika należy zastosować:

- gaz osłonowy argon wg PN - EN ISO 14175 (99,995\%)

- pręty lite LNT 304L Si długość 1000 mm, średnica 2 mm wg PN - EN ISO 14343 (przeznaczone do spawania elementów jednogatunkowych stali wysokostopowych z przeznaczeniem do przemysłu spożywczego, chemicznego).

\section{Nietopliwa elektroda wolframowa}

Do wykonania wymiennika należy zastosować:

- WT2 długość 175 mm, średnicy 2,4 mm do spawania metodą TIG w osłonie argonu prądem stałym stali niskostopowych, wysokostopowych, stopów niklu, stopów tytanu i miedzi.

Skład chemiczny:

- wolfram 98\%

- dwutlenek toru $2 \%$,

\section{Stanowisko do spawania}

Stanowisko składa się z inwertorowego urządzenia spawalniczego Faltig 250DC wyposażonego w uchwyt spawalniczy. Butli 40l gazu osłonowego, przewodu zasilającego i przewodów spawalniczych,uchwytu spawalniczego z elektrodą wolframową WT2 do spawania prądem stałym stali niskostopowych i wysokostopowych. Uchwyt chłodzony jest przepływającym gazem osłonowym. Przyłbica spawalnicza z filtrem samościemniającym działającym w zakresie 9-13 DIN firmy Speedglas. Odzież ochronna.

Dr hab. Inż. Jacek Słania, prof. PCz - Politechnika Częstochowska; mgr inż. Piotr Janowski - EKOMAL S.C., Wieluń.

Autor korespondencyjny/Corresponding author: jacek_slania@poczta.onet.pl 


\section{Technologia spawania}

Parametry spawania (pWPS).

Spawanie należy wykonać metodą TIG zgodnie z opracowanymi wstępnymi instrukcjami pWPS zgodnie z PN EN ISO 15609-1. Złącza teowe, rodzaj spoiny FW, pozycja PB oraz PF. Po przeprowadzeniu kwalifikacji technologii spawania, na stanowiska winny trafić Instrukcje Technologiczne Spawania (WPS), w celu stosowania ich podczas wykonywania prac spawalniczych.

\section{Wymagania stawiane personelowi spawalniczemu}

Całość nadzoru nad pracami spawalniczymi, przy wytwarzaniu wymiennika ciepła należy powierzyć inżynierowi spawalnikowi. Nadzór nad wykonaniem prac spawalniczych należy powierzyć kierownikowi lub brygadziście. Wykonawstwo prac spawalniczych należy powierzyć spawaczom, którzy oprócz podstawowego szkolenia dla spawaczy posiadają aktualne potwierdzone uprawnienia wg PN-EN ISO 9606-1.

\section{Przygotowanie elementów do spawania}

Elementy składowe konstrukcji wymiennika w postaci rur i profili zamkniętych ciąć na pile mechanicznej (taśmowej), po uprzednim wytrasowaniu. Krawędzie rur zaokrąglić w celu usunięcia ostrych krawędzi.

Elementy składowe w postaci blach należy ciąć na laserze CNC (usługa w kooperacji zlecana na zewnątrz), a następnie poddać obróbce gięcia i walcowania.

Powierzchnie podlegające spawaniu oczyścić z foli zabezpieczającej, tłuszczy i innych zanieczyszczeń.

Spoiny sczepne wykonać metodą TIG.

Dla złączy doczołowych podziałka $t$ spoin sczepnych powinna wynieść:

$\mathrm{t}=(20-30)$.

Dla złączy ze spoinami pachwinowymi podziałka $t$ spoin sczepnych powinna wynieść:

$\mathrm{t}=(20-30)$.

Dla złączy doczołowych wartości współczynników a (grubość) oraz I (długość) spoin sczepnych powinny wynieść:

$a=1-3 \mathrm{~mm}, \mathrm{l}=3-5 \mathrm{~mm}$.

Dla złączy ze spoinami pachwinowymi wartości współczynników a (grubość) oraz I (długość) spoin sczepnych powinny wynieść:

$a=1-3 \mathrm{~mm}, \mathrm{I}=3-5 \mathrm{~mm}$.

W przypadku spawania elementów o różnych grubościach ścianki t.j. rury do dna sitowego, parametry spoin sczepnych należy dobrać do mniejszych grubości.

Spawanie konstrukcji wymiennika ciepła wykonywać w hali spawalni zakładu w temperaturze powyżej 5 stopni Celsjusza. Stanowisko powinno być zabezpieczone przed przeciągami. Kolejność wykonywanych operacji montażowych i spawalniczych zawiera Karta Technologiczna Spawania stanowiąca załącznik niniejszego dokumentu.

Po zakończeniu spawania należy wytrawić spoiny.

Uchwyty pomocnicze, służące zespawaniu konstrukcji należy wykonać ze stali identycznej z materiałem rodzimym (X5CrNi18-10). Spawanie elementów pomocniczych winno być prowadzone w sposób analogiczny, jak spawanie spoin sczepnych. Po wykonaniu spawania należy te elementy usunąć poprzez cięcie szlifierkami, lub plazmą ręczną następnie ostre krawędzie stępić. Należy zwrócić szczególną uwagę aby używać tarcz do szlifierek przeznaczonych do stali wysokostopowych.

\section{Prostowanie elementów wymiennika po spawaniu}

Nadmierne odkształcenia po procesach spawalniczych nie maja wpływu na sprawność wymiennika. Zastosowanie palnika olejowego podczas eksploatacji niweluje naprężenia spawalnicze, a zatem nie wykonuje się operacji prostowania w większości przypadków. Prostowanie mechaniczne wymagane jest tylko i wyłącznie w przypadku uniemożliwienia przez odkształcenia spawalnicze montażu elementów współpracujących z wymiennikiem t.j. przyłącze palnika oraz komina spalin.

\section{Dziennik spawania}

Podczas prowadzenia prac spawalniczych wymiennika, należy prowadzić Dziennik Spawania. Prowadzenie Dziennika Spawania należy powierzyć kierownikowi lub brygadziście.

Dziennik Spawania powinien zawierać:

- listę spawaczy uprawnionych do spawania wymiennika;

- potwierdzenie prawidłowej jakości zestawiania i spawania elementów wymiennika, poprzez podpis pracownika Działu Kontroli Jakości. Jeżeli występują odstępstwa od żądanej jakości czy technologii spawania, pracownik Działu Kontroli jakości powinien to odnotowywać w Dzienniku Spawania;

- Dziennik Spawania po wykonaniu prac spawalniczych wymiennika powinien być przechowywany wraz z dokumentacją wykonawczą wymiennika.

\section{Badania złączy spawanych wymiennika}

Wymiennik poddać badaniom wizualnym. Wykonać badanie szczelności oraz wstępne wygrzewanie wymiennika. Wszystkie spoiny powinny mieścić się w poziomie jakości $B$, wg PN-EN ISO 5817. Spoiny pachwinowe podlegają pomiarom długości i grubości.

\section{Naprawa wadliwych złączy}

Wadliwe spoiny należy naprawić poprzez usunięcie wadliwej spoiny i ponowne jej wykonanie. Poprawę wadliwych złączy należy powierzyć spawaczowi, który wykonywał wcześniej dane spoiny. Dopuszcza się ponowne wykonanie usuniętych wadliwych złączy przez innego spawacza, pod warunkiem posiadania przez niego odpowiednich uprawnień.

Naprawę wadliwych spoin należy przeprowadzić z użyciem tych samych materiałów dodatkowych, oraz stosując tą samą metodę spawania.

Po naprawie, wykonane spoiny należy ponownie poddać badaniom wizualnym.

\section{Karta technologiczna spawania wymiennika ciepła $65 \mathrm{~kW}$}

Przed rozpoczęciem prac spawalniczych, należy skompletować dokumentację wykonawczą (t.j rysunki techniczne fotografie jeżeli są dostępne), umożliwiającą przeprowadzenie czynności spawalniczych. Następnie zgromadzić materiały dodatkowe do spawania w postaci butli z gazem osłonowym, drutem elektrodowym itp, a także skontrolować stanowisko do spawania pod kątem BHP i ppoż.

\section{Spawanie komór przejściowych}

W pierwszej kolejności należy wykonać spoiny sczepne naroży komór przejściowych 1, 2 oraz 3 (rys. 1). Następnie należy spawać złącza narożne wg. załączonego rysunku 1 (spoiny pachwinowe) w kolejności i kierunku spawania podanymi na rysunku, obracając komorę tak aby zawsze wykonywać spoiny w pozycji podolnej PA. Po wykonaniu tych czynności należy zamknąć komorę przejściową 2 klapą rewizyjną z wykorzystaniem elementów pomocniczych i pozycjonować klapę w pozycji docelowej. Następnie stosując łączniki z blachy o składzie chemicznym materiału podstawowego wykonać spoiny sczepne na czas trasowania i wiercenia otworów montażowych klapy. Po wykonaniu otworów $\emptyset 8$ odciąć klapy i instalować śruby M8 spawając je w do kołnierza komory w sposób umożliwiający późniejszy montaż klapy rewizyjnej. 

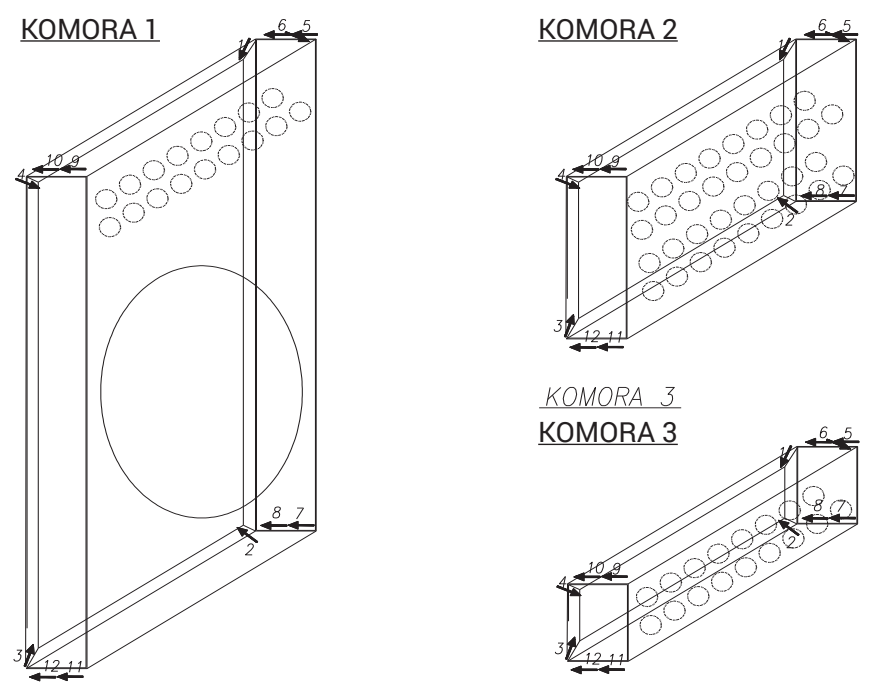

Rys. 1. Kolejność spawania komór [15]

Fig. 1. An order of welding chambers [15]

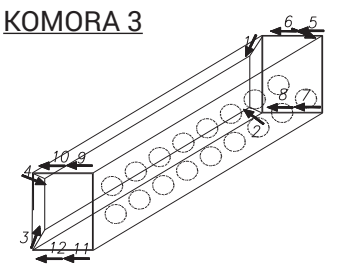

\section{Wstępne spawanie komory spalania}

Zawalcowaną komorę spalania należy sczepiać w jednym końcu z odstępem 1-2 mm umożliwiając późniejsze wykonanie złącza doczołowego w celu zamknięcia obwodu płaszcza. Następnie montować z zastosowaniem spoin sczepnych pokrywę komory spalania i wykonać spoinę pachwinową złącza narożnego komory spalania. Kolejność wykonywania spoin podana na rysunku 2.

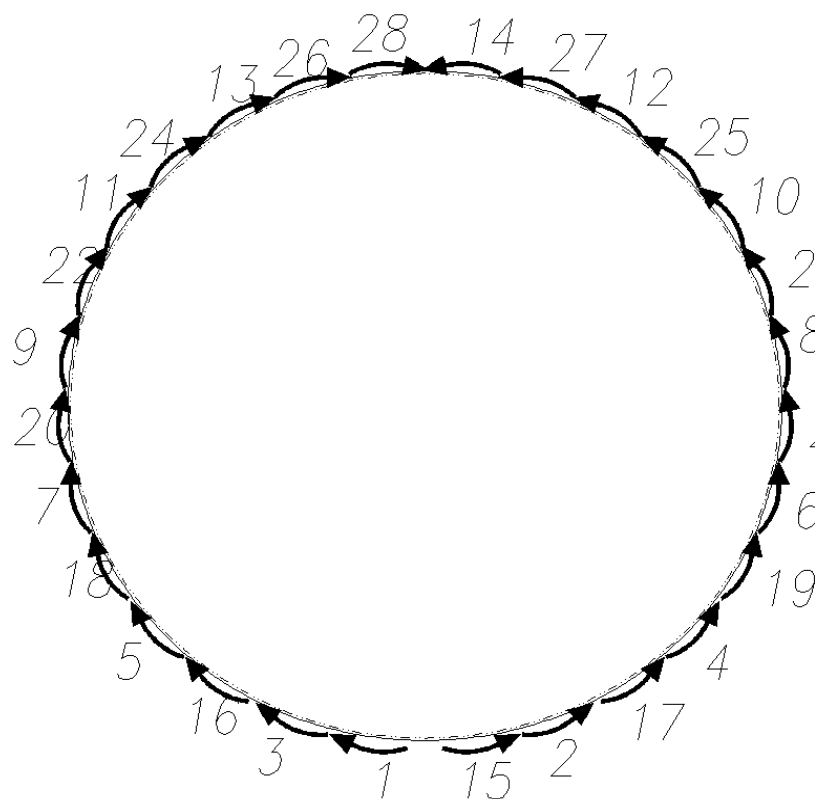

Rys. 2. Kolejność spawania pokrywy komory spalania [15]

Fig. 2. An order of welding the combustion chamber's lid [15]

\section{Montaż i spawanie konstrukcji wymiennika}

Ustawienie na płycie montażowej w zadanej odległości komór przejściowych 1, 2 oraz 3 przytwierdzając je do siebie i podłoża spoinami sczepnymi (do odcięcia). Następnie ustawić rury w pozycjach docelowych i wykonać ich spoiny sczepne. Kolejną czynnością jest ustawienie podpory komory przejściowej 2 i wykonanie spoin sczepnych (do odcięcia). Należy wstawić płaszcz komory spalania w otwór komory przejściowej 1, należy zachować współosiowość z wcześniej zainstalowanymi rurami. Następnie z wykorzystaniem śruby rozporowej należy docisnąć odcinki płaszcza do otworu i wykonać spoiny sczepne. Kolejną czynnością jest wykonanie spoin sczepnych i spawanie płaszcza komory spalania wzdłuż jego osi kolejność podana na rysunku 2. Odciąć wymiennik od płyty montażowej.

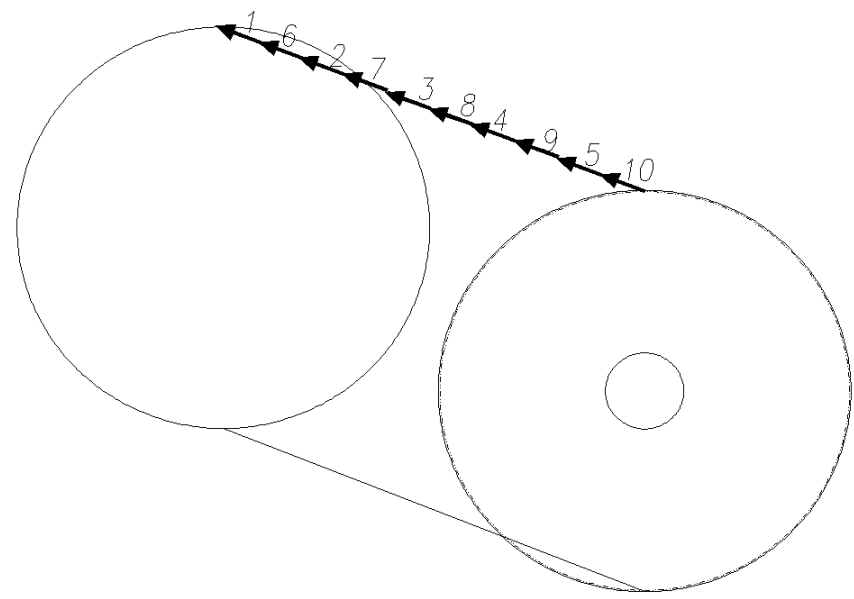

Rys. 3. Kolejność spawania płaszcza komory spalania [15] Fig. 3. An order of welding the combustion chamber's casing [15]

Spawanie wymiennika rozpoczynamy od wykonania spoin obwodowych rur $\emptyset 60,3 \mathrm{~mm}$ do komór przejściowych 1,2 oraz 3 , kolejność i kierunek podany na zaznaczonym rysunku 3, a następnie płaszcza komory spalania do komory przejściowej 1 - rysunek 4 . Spoiny pachwinowe obwodowe rur należy wykonać w pozycji PB obracając wymiennik o $180^{\circ}$. Po wykonaniu tych spoin należy instalować klapę rewizyjną na wcześniej wspawanych śrubach M8 uszczelniając obwodowo z wykorzystaniem maty szklanej. Następnie ustalić położenie pokryw komór przejściowych 1 oraz 3 i wykonać spoiny sczepne. Spoiny pachwinowe obwodowe pokryw należy wykonać w pozycji PB. Kolejność wykonania spoin sczepnych oraz obwodowych ilustruje rysunek 5 .

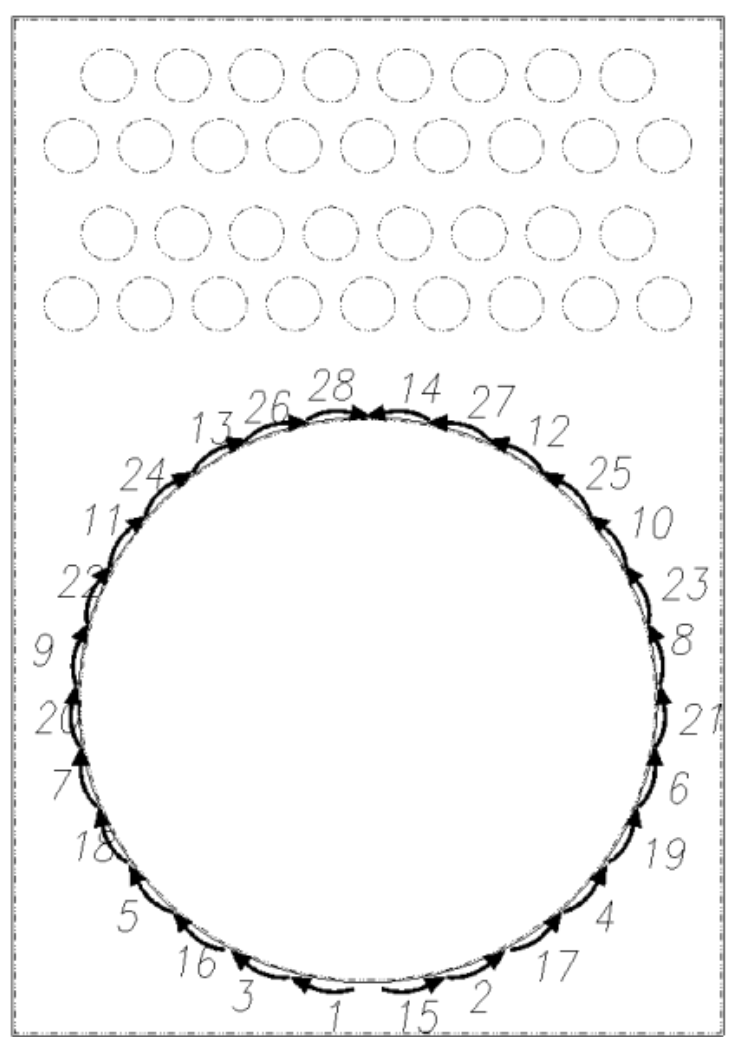

Rys. 4. Kolejność spawania komory spalania do komory przejściowej 1 [15]

Fig. 4. An order of welding a combustion chamber into the transient chamber 1 [15] 

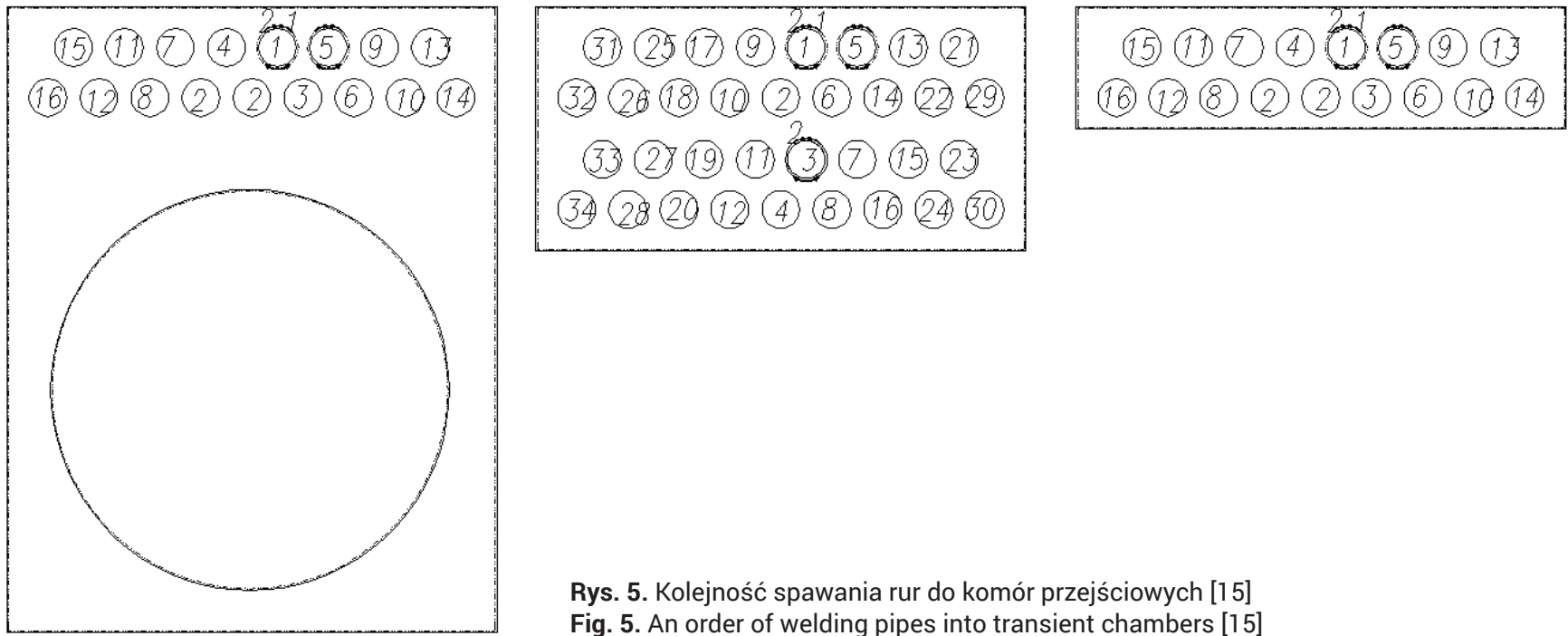

Rys. 5. Kolejność spawania rur do komór przejściowych [15]

Fig. 5. An order of welding pipes into transient chambers [15]

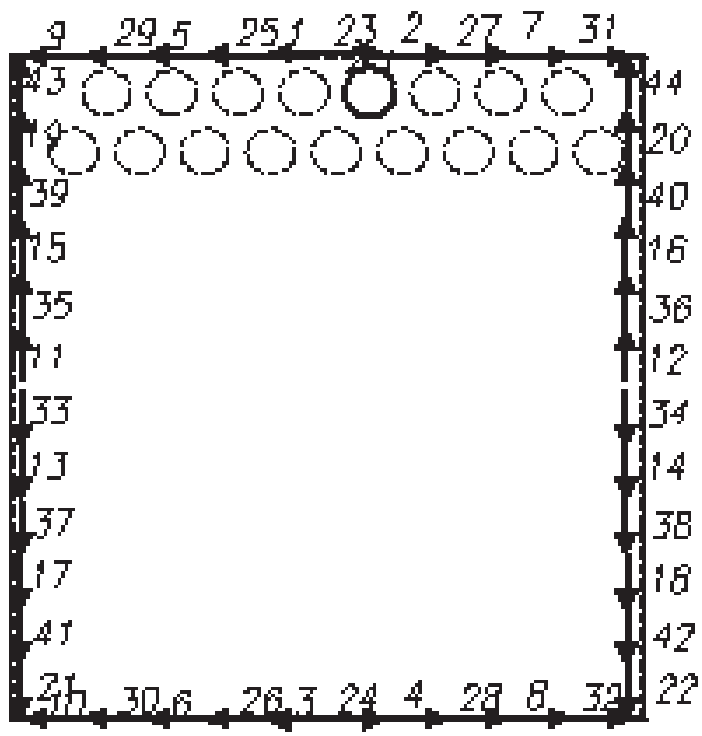

KOMORA 3

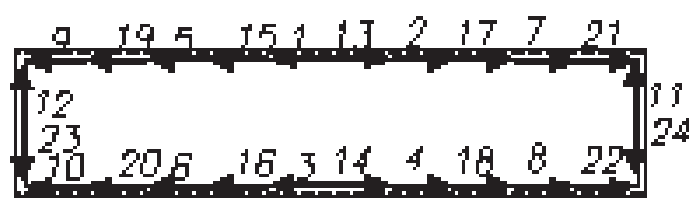

Rys. 6. Kolejność spawania pokryw komór przejściowych [15] Fig. 6. An order of welding transient chambers' lids [15]
Kolejnym etapem jest instalowanie króćca komina spalin, króćca palnika, a następnie montaż ograniczników. Króciec komina $\varnothing 150$ oraz palnika $\varnothing 109$ należy ustawić osiowo w stosunku do rur i komory spalania. Należy wykonać spoiny sczepne i spoiny obwodowe pachwinowe w pozycji PF. Kolejność spawania została podana na rysunku 6.

Po wykonaniu spoin obwodowych należy ustalić pozycje ograniczników oraz wykonać spoiny sczepne i pachwinowe w pozycji PF. Długość spoin została podana na rysunku 7 , a kierunek spawania podany na rysunku 6. Kolejną czynnością jest spawanie kołnierza przyłączeniowego palnika. W pierwszej kolejności należy przyspawać nakrętki M8 w osi otworów $\varnothing 10$ kołnierza. Następnie otwór w kołnierzu ustawić osiowo i prostopadle do rury króćca przyłączeniowego palnika wykonać spoiny sczepne i obwodowe $\mathrm{w}$ pozycji PF wg rysunku 6.

Przeprowadzenie kontroli przez sprawdzenie szczelności i wykonanie wstępnego wygrzewania wymiennika z wykorzystaniem palnika olejowego firmy RIELLO RG1 20-60kW.

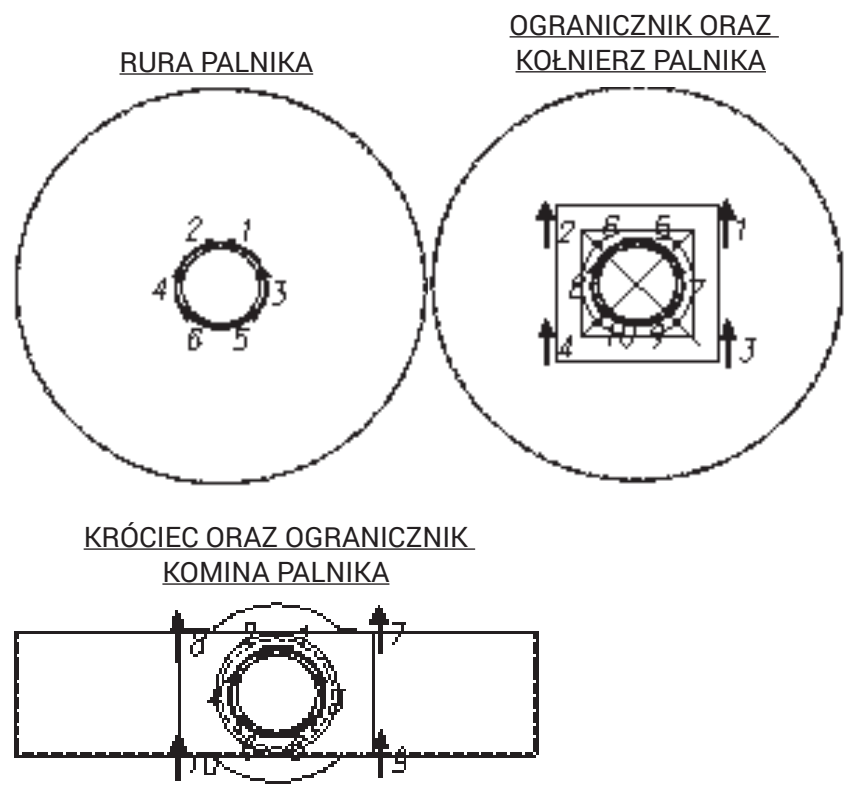

Rys. 7. Kolejność spawania elementów dodatkowych [15] Fig. 7. An order of welding additional elements [15] 


\section{Podsumowanie}

Planowanie procesów spawalniczych jest zalecane dla wszelakich typów konstrukcji. Tylko planowanie i przemyślany algorytm cyklu produkcyjnego przekłada się na produkt oczekiwany efekt końcowy. Dla zapewnienia wysokiej jakości konstrukcji gdzie występują procesy spawalnicze niezbędne jest planowanie począwszy od doboru materiału poprzez zamówienia elementów składowych po nadzór przed w trakcie i po wykonanych pracach spawalniczych.

Przedstawiony plan spawania wymiennika ciepła powinien być ściśle przestrzegany począwszy od zamawiania materiału poprzez jakościowe wycinanie i przygotowanie elementów do spawania. Nadzór wymagany jest od samego początku. Brak kontroli może przełożyć się na utratę poziomu jakości wyrobu np. zbyt duże szczeliny rowków spawalniczych będące wynikiem niedokładnego cięcia, a zatem duży skurcz, odkształcenia. Nie przestrzeganie kolejności spawania może spowodować nadmierne odkształcenia, a nawet pęknięcia spoin [14].

Opracowanie planu spawania ma na celu przeprowadzenie procesu produkcyjnego w sposób prawidłowy umożliwiający jednocześnie spawaczowi prace w najkorzystniejszych pozycjach spawania, przekłada się to na wyniki ekonomiczne i jakościowe produkcji. Każdy z przedstawionych etapów jest ściśle ze sobą powiązany, tylko prawidłowa ich współpraca pozwoli na uzyskanie produktu o wymaganych cechach jakościowych. Każde odstępstwo od zaplanowanych działań może spowodować dodatkowe nieplanowane prace naprawcze, a zatem nakłady finansowe. Tylko przestrzeganie określonych wytycznych prowadzi do uzyskania prawidłowego przebiegu produkcji przy zachowaniu terminów umownych i wymagań jakościowych.

\section{Literatura}

[1] Praca zbiorowa.: Poradnik inżyniera II Spawalnictwo WNT, Warszawa 2005.

[2] Ferenc K.: Spawalnictwo Wydawnictwa Naukowo-Techniczne Warszawa 2005.

[4] Tasak E.: Metalurgia spawania Wydawnictwo JAK Andrzej Choczewski 2008.

[5] Domański S.: Ślusarstwo i spawalnictwo z materiałoznawstwem Wydawnictwa Szkolne i Pedagogiczne Warszawa 1973.

[6] Kurpisz B.: Technologiczne plany spawania. Skrypt, Gliwice, 1991.

[7] Mazur M.: Podstawy Spawalnictwa Wydawnictwo Politechniki Śląskiej Gliwice 1993

[8] Grundmann J.: Wpływ zawartości $\mathrm{CO}_{2} \mathrm{w}$ argonie na wydajność i efektywność procesu spawania MAG. Biuletyn Instytutu Spawalnictwa nr 5/2012, str. 145-149.

[9] Dobaj E.: Maszyny i urządzenia spawalnicze (wydanie drugie). Wydawnictwa Naukowo Techniczne Warszawa 1994, 2005.

[10] Myśliwiec M.: Spawalnictwo Wydawnictwa Naukowo - Techniczne Warszawa 1981.

[11] Pierożek B., Lassociński J.: Spawanie łukowe stali w osłonach gazowych Wydawnictwa Naukowo - Techniczne Warszawa 1987.

[12] Biały W.: Maszynoznawstwo Wydawnicawa Naukowo - Techniczne Warszawa 2003.

[13] Opartny-Myśliwiec D., Myśliwiec M.: Techniki wytwarzania spawalnictwo Państwowe wydawnictwo naukowe 1981.

[14] Słania J., Skóra J.: Plan spawania wymiennika ciepła chłodzonego powietrzem, Przegląd Spawalnictwa, nr 2/2011, str. 19-26.

[15] Źródło własne.

[16] Słania J.: Plany spawania. Teoria i praktyka. Agenda Wydawnicza SIMP, Warszawa 2013.

[17] Słania J.: Plan technologiczny spawania płyty gąsienicowej. Przegląd Spawalnictwa, 2010, nr 3, str. 16-25.

[18] Słania J., Kaczor T.: Plan spawania zbiornika ciśnieniowego. Przegląd Spawalnictwa, 2010, nr 4, str. 9-18.

[19] Słania J., Kwiecień L., Jarosiński J.: Plan spawania kotłów płomienicowopłomieniówkowych. Przegląd Spawalnictwa, 2010, nr 6, str. 32-40.

[20] Słania J., Skóra J.: Plan spawania wymiennika ciepła chłodzonego powietrzem. Przegląd Spawalnictwa 2011, nr 2, str. 16-22.

[21] Słania J.: Plan spawania carg płaszcza pieca obrotowego. Przegląd Spawalnictwa 2011, nr 2, str. 36-41.

[22] Słania J., Wodecki D.: Plan spawania belki poprzecznej dźwigu. Przegląd Spawalnictwa 2011, nr 2, str. 30-35.

[23] Słania J.: Istota planów spawania. Przegląd Spawalnictwa 2011, nr 2, str. 3-9.

[24] Słania J.: Plan spawania napraw bieżących kotłów parowych, wodnych i stałych zbiorników ciśnieniowych. Przegląd Spawalnictwa 2011, nr 2, str. 22-30.

[25] Słania J., Kwiecień L., Jarosiński J.: Kotły płomienicowo-płomieniówkowe - plan spawania oraz kontroli i badań. Dozór Techniczny 2011, nr 2, str. $35-41$.

[26] Słania J., Chomiuk S., Dadak R.: Plan spawania dla konstrukcji uzupełniającej - trawresy. Przegląd Spawalnictwa 2012, nr 2, str. 3-6.

[27] Słania J., Marcinkiewicz H., Kiełbik M.: Plan spawania elementu obudowy kopalnianej - osłony odzawałowej. Przegląd Spawalnictwa 2012, nr 2, str. 6-16.

[28] Słania J., Fryc H.: Spawanie pojazdów szynowych - plany spawania. Przegląd Spawalnictwa 2012, nr 2, str. 16-20.

[29] Słania J.: Plan spawania stalowej kładki dla pieszych I. Przegląd Spawalnictwa 2012, nr 2, str. 20-24.

[30] Słania J.: Plan spawania stalowej kładki dla pieszych II. Przegląd Spawalnictwa 2012, nr 2, str. 24-26.

[31] Słania J., Urbańczyk P.: Technologia wytwarzania oraz plan kontroli jakości przegrzewacza pary kotła parowego wg PN-EN 12952-5. Przegląd Spawalnictwa 2012, nr 5, str. 29-41.

[32] Chromik D., Słania J.: Plan spawania ciśnieniowego zespołu rurowego. Przegląd Spawalnictwa 2012, nr 11, str. 29-32.

[33] Balcerzak M., Słania J.: Spawanie zbiornika bezciśnieniowego do magazynowania oleju opałowego. Przegląd Spawalnictwa 2012, nr 11, str. 33-38. 